\title{
Slawomir Dorocki
}

Zakład Przedsiębiorczości i Gospodarki Przestrzennej

Instytut Geografii

Uniwersytet Pedagogiczny im. Komisji Edukacji Narodowej w Krakowie

\section{Gospodarka oparta na wiedzy w zalożeniach Strategii Lizbońskiej - na przykładzie Francji}

Jedną z głównych przyczyn powstania Europejskiej Wspólnoty Węgla i Stali, a w konsekwencji -Europejskiej Wspólnoty Gospodarczej w latach 50. XX w. był spadek znaczenia Europy w gospodarce światowej. Zmiany, głównie w sektorach przemysłu ciężkiego i rolnictwa, doprowadziły w latach 90. XX w. do wyraźnego osłabienia gospodarki UE, zwłaszcza w porównaniu ze Stanami Zjednoczonymi. Wyrażało się to głównie wolniejszym tempem rozwoju oraz mniejszą zdolnością tworzenia i absorpcji nowych technologii w warunkach postępującej globalizacji ${ }^{1}$.

Aby przeciwdziałać tej niekorzystnej tendencji, w 2000 r. w Lizbonie szefowie państw Unii Europejskiej uchwalili wspólną strategię ekonomiczną i społeczną, mającą na celu przekształcenie unijnej gospodarki w najbardziej konkurencyjną i dynamiczną gospodarkę na świecie. Osiagnięciu tych celów ma służyć m.in. szybkie przechodzenie do gospodarki opartej na wiedzy, rozwój społeczeństwa informacyjnego, badania i zwiększenie innowacyjności gospodarki oraz kształcenie w społeczeństwie odpowiednich kwalifikacji i umiejętności. W tym celu przewidziano, że do 2010 r. 3\% PKB (z czego $2 / 3$ ma pochodzić z sektora przedsiębiorstw) zostanie przeznaczone na edukację, prace badawczo-rozwojowe oraz na wprowadzanie mechanizmów rozpowszechniania wiedzy i informacji. Wzrost efektywności działań ma przynieść koordynacja polityk (regionalnych, krajowych i europejskiej) oraz stworzenie wewnętrznego rynku badań, obszaru swobodnego przepływu wiedzy, badaczy i technologii, który ma doprowadzić do zacieśnienia współpracy, uaktywnienia rywalizacji oraz osiagnnięcia lepszej alokacji dostępnych zasobów.

Podstawowym instrumentem Strategii Lizbońskiej w sferze rozwoju wiedzy i innowacji są programy ramowe. Obecnie jest realizowany 7. program ramowy na lata 2007-2013 o wartości 53 mld euro, a w nim - cztery programy: współpraca (koordynacja badań), pomysły (wspieranie badań we wszystkich dziedzinach nauki i technologii, łącznie z inżynierią, naukami społeczno-ekonomicznymi i humanistycznymi), ludzie (szkolenia i rozwijanie kariery naukowców) i możliwości (wspieranie kluczowych dziedzin badań i innowacji).

Efektem realizacji tych programów ma być Europejska Przestrzeń Badawcza (European Research Area-ERA), w której skład wchodziłyby europejskie bieguny konkurencyjności i klastry Eureka.

Tematem niniejszego artykułu są działania Francji mające na celu rozwój gospodarki opartej na wiedzy oraz przestrzenne zróżnicowanie inwestycji. Jest on oparty na danych i informacjach zamieszczonych na stronach internetowych instytucji rządowych Francji.

\footnotetext{
${ }^{1} \mathrm{~W}$ ciagu ostatnich 20 lat Unia rozwijała się w tempie 2,3\% rocznie, a Stany Zjednoczone - w tempie 3,3\% rocznie.
} 
Francuski Narodowy Program Reform jest zbudowany na podstawie założenia „,wzrostu społecznego", dlatego w dziedzinie badań i innowacji planuje się w nim zwiększenie prywatnych inwestycji w tym sektorze, poprawę efektywności badań publicznych i pomoc w popularyzowaniu innowacji w gospodarce. Głównymi celami programu są: koordynacja badań publicznych i intensyfikacja współpracy z przedsiębiorstwami oraz rozwój innowacyjności i polityki przemysłowej. Osiagnięciu tych celów mają służyć: usprawnienie współpracy między podmiotami gospodarczymi i instytucjami, m.in. poprzez zmiany prawa pracy, ulgi, lepszy dostęp do finansowania, rozpowszechnianie technologii informacyjnych i komunikacyjnych oraz zwiększenie środków na rozwój lokalny i poprawę infrastruktury technicznej.

W ramach trzeciego priorytetu francuskiego narodowego programu rozwoju „Budowa gospodarki opartej na wiedzy” wyróżnia się trzy sfery przedsięwziąć. Jedną z nich jest „Pobudzanie badań i innowacji", w której podejmowane są trzy rodzaje działań:

- zwiększenie środków finansowych i skuteczności badań publicznych poprzez lepsze sformułowanie i ocenę polityki naukowej;

- rozwój współpracy i popularyzowanie francuskich osiągnięć naukowych na arenie międzynarodowej, polepszenie atrakcyjności kariery naukowej i integracji francuskiego systemu badań w przestrzeni europejskiej;

- rozwijanie nauki poprzez rozwój skuteczności współfinansowania prywatno-publicznego.

Ryc. 1. Przestrzenne rozdysponowanie środków finansowych z funduszu ANR w 2006 r. we Francji (wartość całkowita dotacji $621 \mathrm{mln}$ euro)

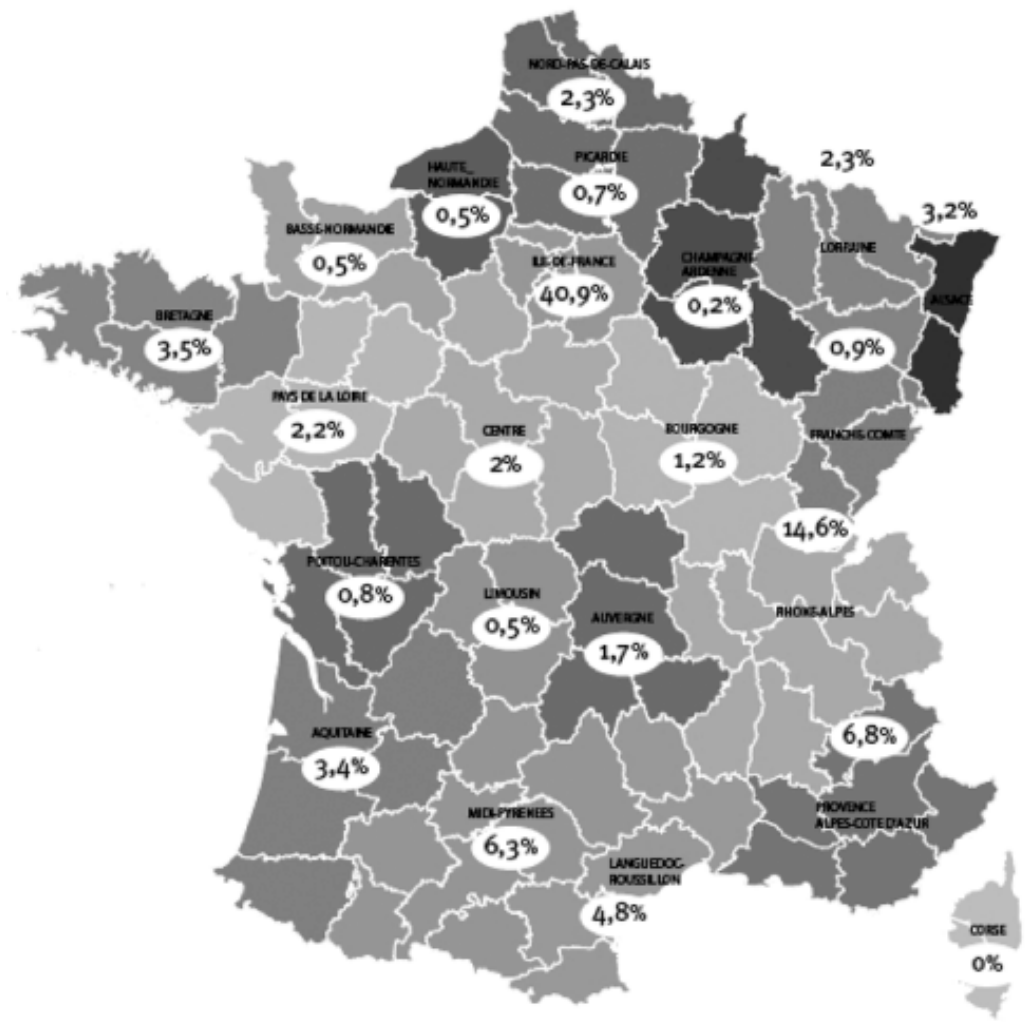

Źródło: Rapport ANR 2006.

Działania te realizowane są przez odpowiednie organy. Przykładem może być Narodowa Agencja ds. Badań (Agence National de la Recherche - ANR) utworzona w celu finansowania projektów badawczych zarówno publicznych jednostek badawczych, jak i przedsiębiorstw. Celem jest tworzenie nowej wiedzy oraz wspieranie współpracy publicznych placówek badawczych i laboratoriów przedsiębiorstw poprzez tworzenie partnerstwa. ANR w 2007 r. otrzymała 825 mln euro na projekty naukowe trwające maksymalnie cztery lata. Geograficzny podział finansowania projektów 
wykazał dużą koncentrację, skupiając w regionie Île-de-France (aglomeracja Paryża) 40,9\% ogółu dotacji; następne były regiony Rhône-Alpes (14,6\%) i Provence-Alpes-Côte d'Azur $(6,8 \%)^{2}$.

Do promocji i wsparcia dużych innowacyjnych przedsięwzięć przemysłowych została powołana Agencja ds. Innowacji Przemysłowych (Agence de l'Innovation Industrielle - AII). Agencja ogłasza przetargi na duże projekty średniookresowe, współfinansowane przez przemysłowców, zgodnie z przepisami europejskimi, wymagające wysiłku badawczo-rozwojowego. W pierwszym programie realizowanym od 2006 r. ujęto:

- BioHub, rozwój rolnictwa przez biotechnologię (firma realizująca: Roquette Frères) w regionach Nord-Pas de Calais, Lyon/Rhône Alpes;

- Homes, energooszczędny budynek (Schneider Electric) - Rhône-Alpes;

- NeoVal, system automatycznego transportu na ogumieniu (Siemens Francja) - Cachin/Île-de-France;

- Quaero, przeszukiwanie i rozpoznawanie informacji w sieciach internetowych (Thomson) Bretagne;

- Tvmsl, Telewizja mobilna (Alcatel);

- VHD, samochody z napędem hybrydowym (Peugeot, Citroen, PSA) - Île-de-France, Poitou-Charentes.

Ryc. 2. Ośrodki przemysłowo-badawcze korzystające z funduszu All w 2006 r.

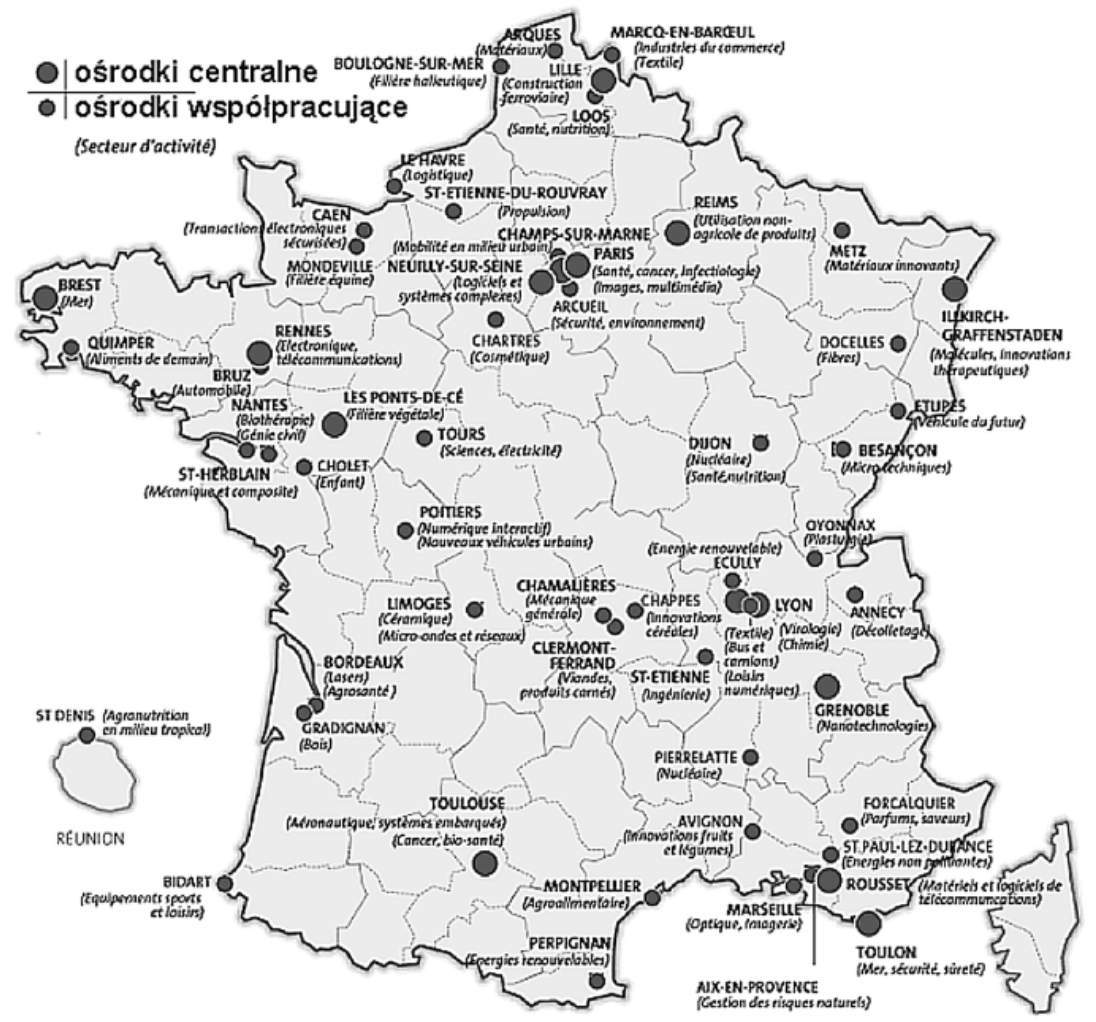

Źródło: http://www.spyworld-actu.com/IMG/_article_PDF/article_676.pdf

Osobna instytucja powstała w celu wspierania innowacji mniejszych przedsiębiorstw - OSEO (Le groupe OSEO au service de l'entrepreneur). OSEO ma szczególne powiązanie ze wszystkimi MSP na każdym etapie ich rozwoju. W całej Francji te przedsiębiorstwa mogą wykorzystywać techniczno-ekonomiczne możliwości inżynieryjne OSEO, specjalistyczną wiedzę finansową

\footnotetext{
${ }^{2}$ http://www.agence-nationale-recherche.fr/documents/uploaded/2007/Rapport-ANR-2006.pdf
} 
i usługi serwisów. Organizacja wspiera projekty o charakterze bardzo innowacyjnym poprzez współfinansowanie projektów do 40-70\% wartości, udzielanie gwarancji podczas negocjacji $\mathrm{z}$ instytucjami bankowymi i finansowymi (OSEO Financement \& Garantie), oferuje usługi on-line i prowadzi badania rozwoju MSP. Ponadto OSEO zajmuje się przyznawaniem subwencji i kredytów firmom zainteresowanym stosowaniem nowych technologii oraz nadaje firmom tytuł „Firmy innowacyjnej” (Societe Innovante), który uprawnia do korzystania z dotacji. OSEO działa w 7 dużych regionach: Nord Ouest, Bretagne, Grand Est, Sud Est, Sud Méditerranée, Centre Atlantique, Île-de-France. Według liczby realizowanych projektów w 2006 r. można wyodrębnić dwa regiony rozwoju sektora innowacji: Île-de-France i Rhône-Alpes, istnieje również wyraźna dominacja regionów południowych Francji nad częścią północną pod względem liczby realizowanych projektów.

Ryc. 3. Liczba przedsiębiorstw korzystająca z subwencji OSEO na 10 tys. mieszkańców w 2005 r.

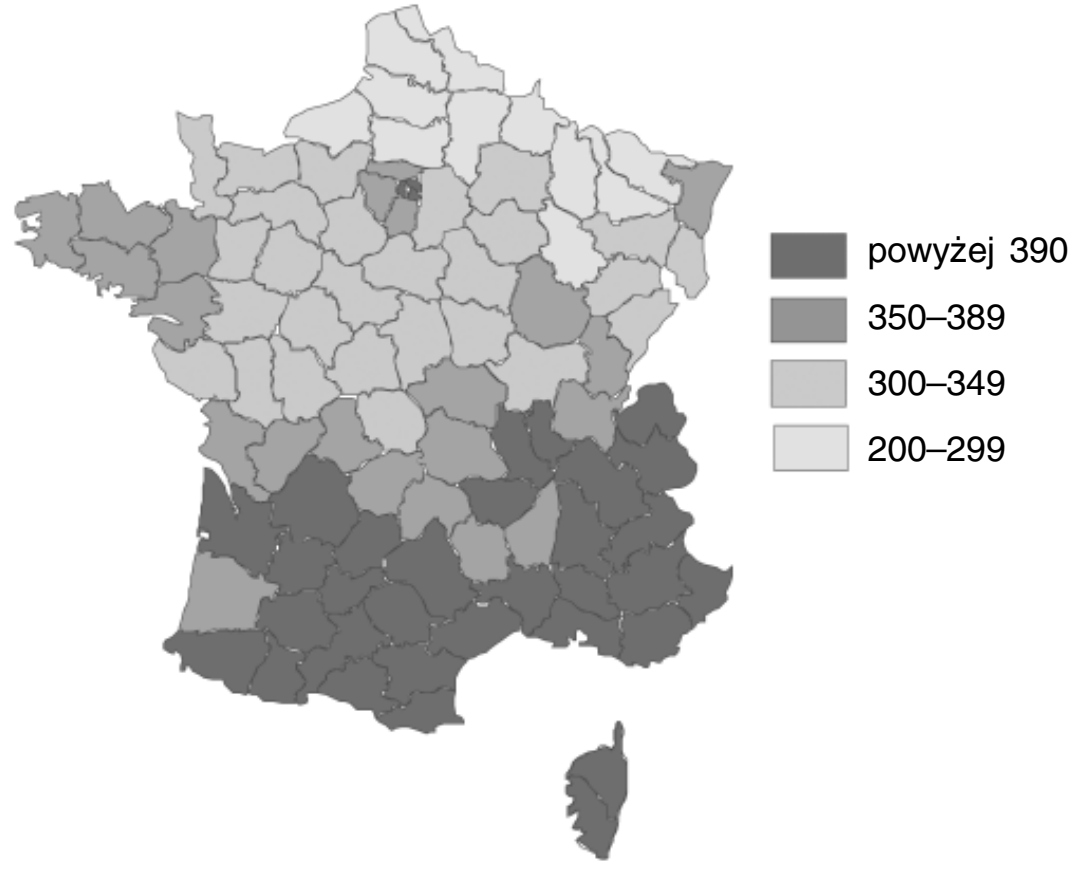

Źródło: opracowanie na podstawie Rapport OSEO sur l'évolution des PME.

Innym przykładem przedsięwzięć mających wspomagać rozwój innowacyjności wśród przedsiębiorstw są specjalne jednoosobowe spółki inwestorów (Société Unipersonnelle d'Investisseurs a Risque - SUIR), działające na zasadzie „Business Angel” (tzw. „aniołów biznesu”). Mają one za zadanie kierowanie kapitału do przedsiębiorstw innowacyjnych poprzez 10-letnie ulgi dla inwestorów. Ponadto zmodernizowano wspólne fundusze inwestowania w innowacje (Fonds communs de placement innovation - FCPI), wspomagające na zasadzie ulg inwestycyjnych głównie firmy z grupy tzw. spin-offs, łączące branże technologii informacyjnych, biotechnologię i energetykę. Innym przykładem jest wprowadzenie rządowych gwarancji SOFARIS (Société Francaise de garantie des financements des Petites et Moyennes Entreprises) o wysokości 30$50 \%$ wartości inwestycji (możliwość 70\% dla przedsiębiorstw tworzonych od podstaw) niezbędnych do otrzymania pożyczki bankowej dla projektów innowacyjnych zgłaszanych przez MSP.

Innym narzędziem finansowym wspierającym rozwój firm jest pomoc dla projektów młodych przedsiębiorstw innowacyjnych (Aide aux projets des Jeunes Entreprises Innovantes - APJEI), która pozwala MSP działającym samodzielnie krócej niż 8 lat, zatrudniającym mniej niż 250 pracowników i ponoszącym wydatki na rozwój i badania przynajmniej w wysokości $15 \%$ całkowitych kosztów działalności, na znaczne zwolnienia podatkowe. Podobne zadanie ma badawczy 
kredyt podatkowy (Crédit d'impôt recherche-CIR), ustanowiony w latach 80. XX w. jako jeden z pierwszych programów przywilejów podatkowych i uzupełniony w 2004 r. projektem „Młode innowacyjne przedsiębiorstwa" (Jeune Entreprises Innovantes - YIC). Program wspiera przedsiębiorstwa prowadzące działalność w zakresie badań i rozwoju (B+R), których koszty kwalifikowane obejmują płace pracowników naukowych, koszty materiałów, infrastruktury badawczej i innego wyposażenia oraz koszty badań zleconych. CIR wspiera również finansowo działalność badawczą uczelni wyższych i publicznych instytucji badawczych.

Ryc. 4. Bieguny konkurencyjności w 2006 r. i planowane w 2007 r.

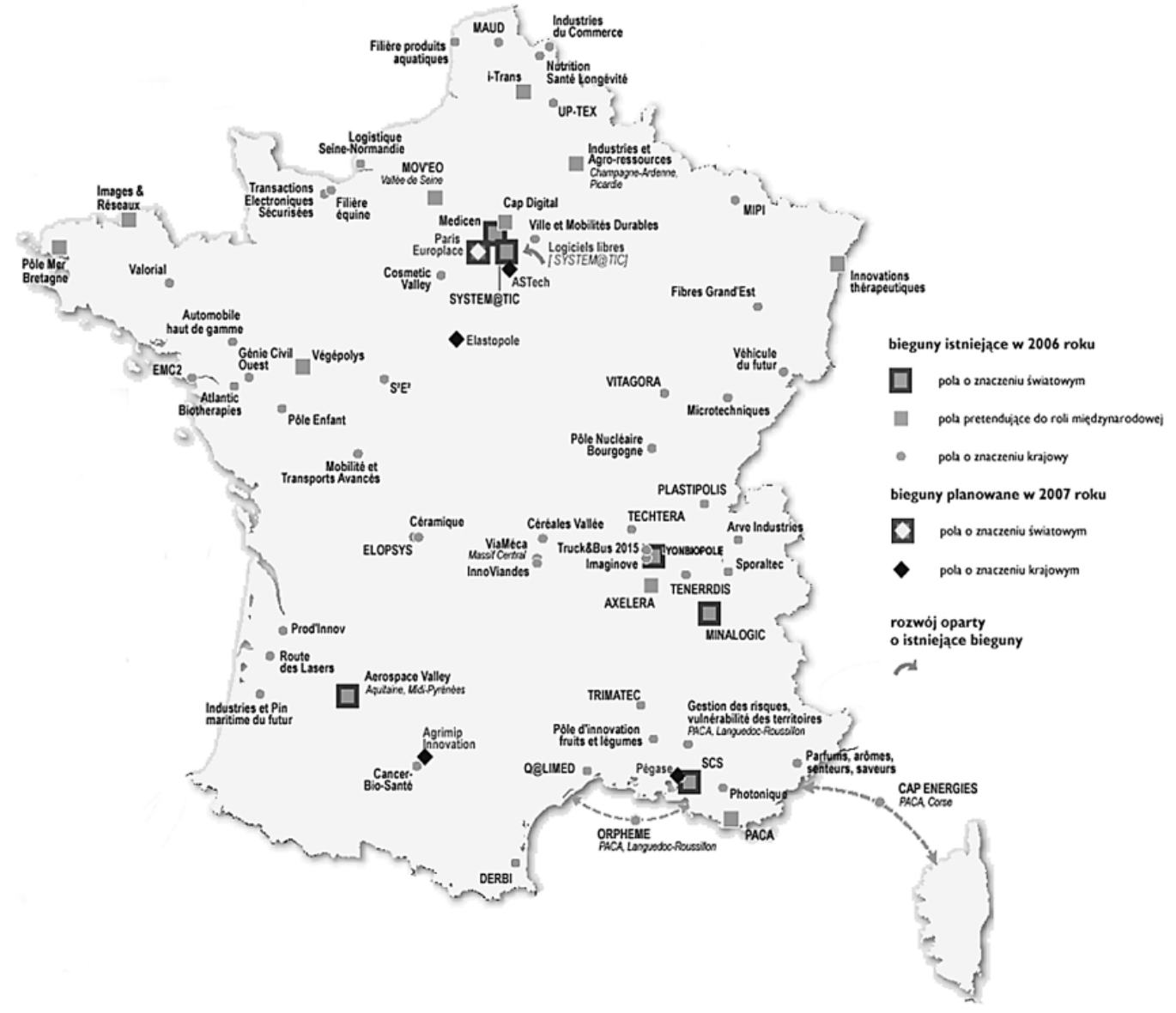

Źródło: www.competitivite.gouv.fr

W związku z tym, że motorem wzrostu francuskiej gospodarki jest przemysł, będący zarazem głównym źródłem innowacji ( 90 \% ogółu wydatków B+R) i konkurencji (80\% eksportu), w 2004 r. powołano we Francji tzw. bieguny konkurencyjności (pôles de compétitivité), będące terytorialnymi klasterami przemysłowymi. W skład klastera weszły przedsiębiorstwa, ośrodki badawcze, władze lokalne i różnego typu podmioty skupione wokół wspólnych projektów innowacyjnych.

W założeniach głównymi elementami sukcesu bieguna są: całkowita spójność strategii rozwoju z obszarem, partnerstwo między podmiotami skupionymi wokół projektu, koncentracja na rozwoju zaawansowanych technologii oraz znaczenie międzynarodowe. Według Międzyresortowego Komitetu ds. Zagospodarowania i Rozwoju Terytorialnego (CIADT - Comité Interministériel d'Aménagement et de Développement des Territoires), w lipcu 2007 r. przyjęto do realizacji 71 „,biegunów konkurencyjności”, z których 7 ma wymiar światowy, a 10 ku takiemu wymiarowi zmierza. Bieguny będą miały dostęp do pomocy publicznej, którą na lata 2006-2008 przewiduje się w wysokości 1,5 mld euro). 
Według bilansu finansowego z 2006 r., najwięcej dotacji (około 34\% ogółu dotacji w biegunach z 533 mln euro) otrzymał sektor TIC (technologie informacyjne i komunikacyjne), następne w kolejności były sektory biotechnologii, zdrowia i spożywczy. W układzie terytorialnym największe wartości inwestycji zgromadzono w regionie Île-de-France (23\%) i Rhône-Alpes (18\%). Regiony z ponad 10-procentowym udziałem kumulacji finansowej to Provence-Alpes-Côte-d'Azur, Aquitaine, Midi-Pyrénées i Bretagne.

Ryc. 5. Liczba biegunów konkurencyjności według regionów w 2006 r.

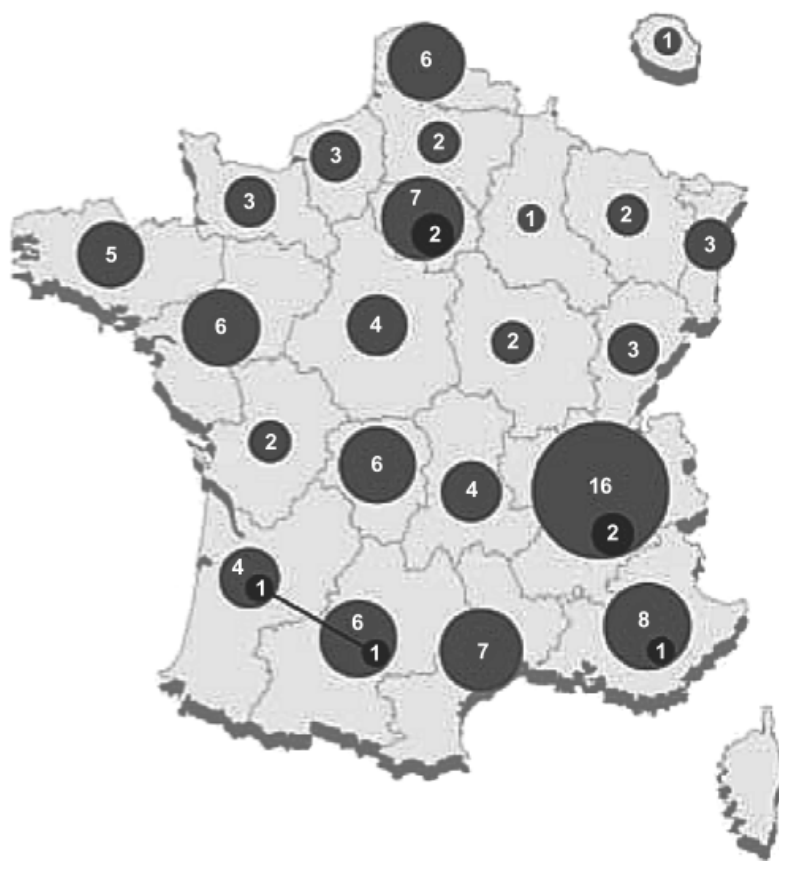

Źródło: www.competitivite.gouv.fr

Ryc. 6. Udział biegunów konkurencyjności w dotacji ogółem w 2006 r. (w \%; 533 mln euro całości dotacji)

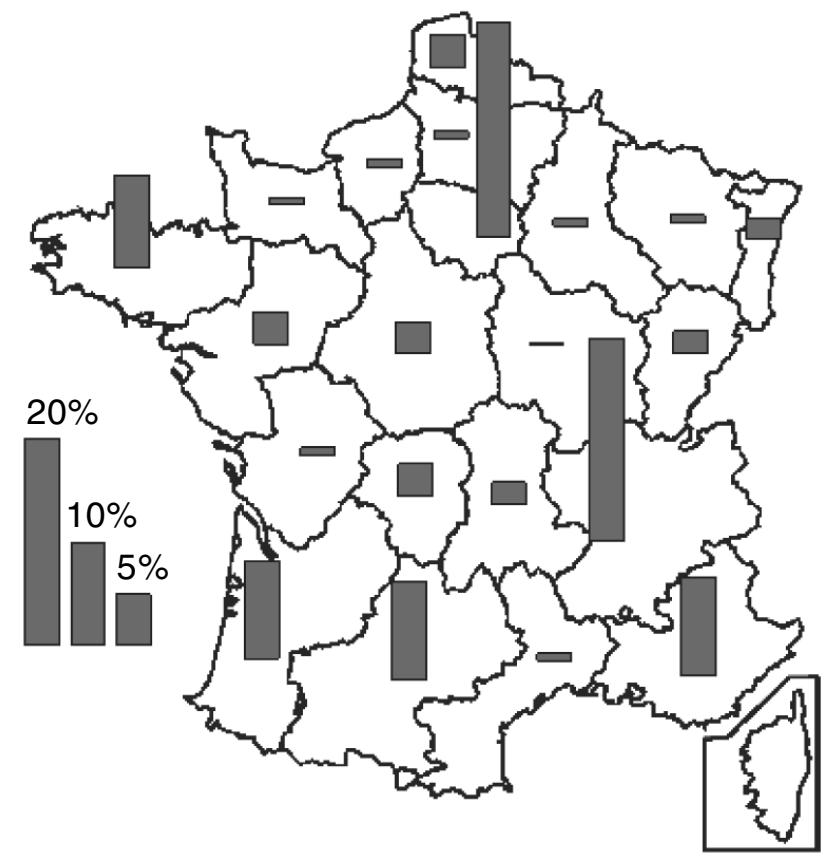

Źródło: opracowanie na podstawie Rapport OSEO sur l'évolution des PME. 
Bieguny konkurencyjności są przykładem działań wchodzących w skład paktu na rzecz badań (Pacte pour la recherche). Jest to program działań rządu francuskiego, którego celem jest prowadzenie polityki krajowej spójnej z rozwojem nauki i badań, aby utrzymać najwyższy poziom sektora badawczo-rozwojowego w odniesieniu do międzynarodowej konkurencji. Pakt zawiera sześć głównych celów:

- wzmocnienie priorytetów francuskich badań;

- budowa jednolitego, spójnego i przejrzystego systemu ewaluacji badań;

- rozwój współpracy między głównymi podmiotami sfery badawczo-rozwojowej;

- stworzenie karier naukowych bardziej atrakcyjnymi;

- wsparcie wysiłku badawczego przedsiębiorstw, szczególnie w zakresie nawiązania ściślejszych powiązań między projektami badawczymi publicznymi i prywatnymi;

- integracja francuskiego systemu badawczego w europejskiej przestrzeni naukowej.

Działania podejmowane w nawiązaniu do tych założonych celów polegają głównie na zapewnieniu dodatkowych środków finansowych na wdrożenie działań paktu do 2010 r. Środki te będą wspomagały głównie badania publiczne, ale przewidziano także pewną część na działania badawcze przedsiębiorstw, przekładające się na wzrost gospodarczy i wzrost zatrudnienia. Przykładem może być reforma związana z możliwościami uzyskania stopnia doktora. W $2007 \mathrm{r}$. przewidziano 3,36 mln euro dla 500 doktorantów, które to środki mają być przeznaczone m.in. dla przedsiębiorstw jako ulgi związane z podnoszeniem kwalifikacji pracowników, którzy zdecydują się na uzyskanie stopnia doktora. Ponadto zakłada się, że w kolejnych latach o $10 \%$ wzrośnie liczba prac doktorskich, które powstaną jako wynik współdziałania uczelni z przedsiębiorstwami. Inną zmianą ma być podniesienie znaczenia tytułu doktora na rynku pracy.

Ryc. 7. Struktura finansowania według sektorów we francuskich biegunach konkurencyjności w 2006 r. (\% ogółu dotacji)

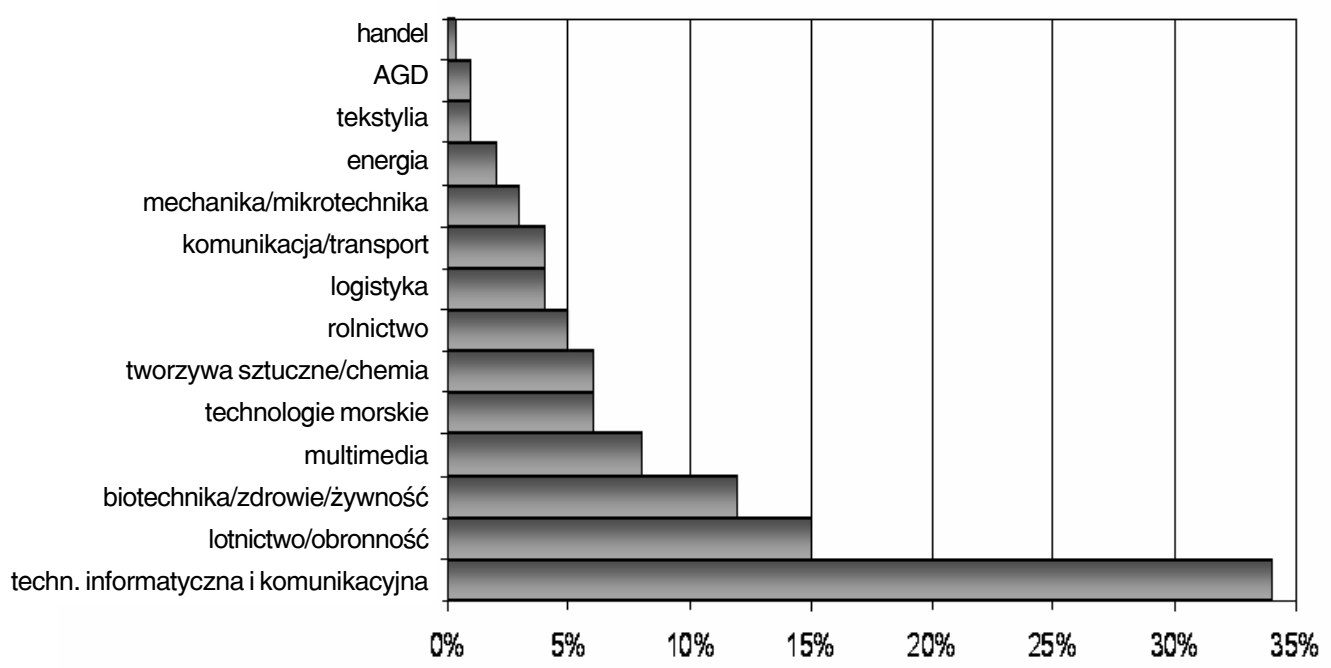

Źródło: opracowanie na podstawie danych: http://www.competitivite.gouv.fr.

Wszystkim tym działaniom towarzyszy priorytet 3.3 francuskiego narodowego programu rozwoju dotyczący promocji, tworzenia i rozpowszechniania technologii informacyjnych i komunikacyjnych. Podjęte w ramach tej akcji działania związane są z bezpieczeństwem funkcjonowania sieci informatycznych i zapewnieniem powszechnego do nich dostępu, zwłaszcza w sektorze MSP. W priorytecie tym wskazuje się na państwo jako głównego aktora społeczeństwa informacyjnego. 
Wynikiem podjętych działań na rzecz rozwoju społeczno-gospodarczego jest drugie w Europie (po Niemczech) i czwarte (po Stanach Zjednoczonych, Japonii i Niemczech) miejsce współczesnej gospodarki francuskiej na świecie. Charakterystyczną cechą gospodarki francuskiej jest szybko rosnący udział sektora zaawansowanych technologii, który generuje ponad 80\% wpływów eksportowych kraju. Na pewno duże znaczenie w przypadku Francji ma polityka państwa, która w porównaniu z polityką Stanów Zjednoczonych jest bardzo scentralizowana. Pomoc państwa w rozwoju gospodarki opartej na wiedzy obejmuje głównie subsydia i zwolnienia podatkowe ${ }^{3}$ w zakresie badań i rozwoju ${ }^{4}$. Przykładem może być dofinansowanie inwestycji do wysokości 75\% wydatków na prace badawcze czy na wprowadzanie nowych rozwiązań do przedsiębiorstw. Oprócz przyznawania ulg, państwo pomaga w nawiązywaniu współpracy międzynarodowej poprzez tworzenie europejskiego partnerstwa technologicznego, nadawanie statutu ,młodego przedsiębiorstwa innowacyjnego” oraz wsparcie finansowe w celu przyciagnięcia najlepszej kadry badawczej z zagranicy oraz młodych, zdolnych naukowców.

Potwierdzeniem celowości wymienionych zabiegów jest to, że pod względem wskaźników obrazujących rozwój sektora B+R Francja znajduje się w czołówce państw europejskich i światowych, a region Île-de-France od 2001 r. zajmuje pierwsze miejsce pod względem rozwoju technologicznego wśród wszystkich regionów europejskich.

\section{Literatura}

1. http://europa.eu.int/comm/eurostat/ (Science and Technology, Highest proportion of graduates in Science $\&$ Engineering in Sweden, Ireland and France)

2. http://www.agence-nationale-recherche.fr/documents/uploaded/2007/Rapport-ANR-2006.pdf

3. http://www.competitivite.gouv.fr

4. http://www.euroinfo.krakow.pl/uploaded_files/Strategia_rozwoju_innowacji_w_krajach_UE_przykladzie_Polski_Francji.doc

5.http://www.spyworld-actu.com/IMG/_article_PDF/article_676.pdf

\section{Knowledge-based Economy in the Premises of Lisbon Strategy. The Case of France}

In spite of the process of economic integration in Europe, a lot of developed countries surpass it in the area of industrial development based on the knowledge. Therefore, in 2000 in Lisbon the heads of EU countries accepted the common economic and social strategy for the transformation of EU into the most dynamic and competitive economy in the world. To reach this goal a quick transformation into knowledge-based economy, the development of information society and the increase of economic innovation are planned.

\footnotetext{
${ }^{3}$ Podwyższenie progu wolnego od opodatkowania funduszy na badania z 6,1 do 8,2 mln euro na przedsiębiorstwo.

${ }^{4}$ Jeżeli dany program badawczy nie jest bezpośrednio subsydiowany, firma może otrzymać do około $6,1 \mathrm{mln}$ euro zwolnień podatkowych rocznie.
} 
The following article presents the steps France is taking in the framework of National Reform Programme based on "social increase". It assumes that in the area of research and innovation the increase of private investment and the increase of effectiveness of public research and help in popularizing innovations in economy are planned. The main aim of the programme is to coordinate public research and intensify the cooperation with enterprises and development of innovation and industrial politics. The plans to reach these aims consist of the change the labor law, concessions, better access to funds, the promotion of IT and the increase of funds for local development and the improvement of technical infrastructure.

The third priority, "the formation of economy based on knowledge", distinguishes three spheres of enterprises. One of them is "the stimulation of research and innovation" which deals with:

- the increase of funds and effectiveness of public research by means of better formulation and estimation of scientific politics

- the development and popularization of French scientific achievements, the improvement of attractiveness of scientific career and the integration of French research system in Europe

- the development of science by means of projects and the improvement of effectiveness of public-private co-financing.

Apart from the steps taken, spatial differentiation of development of $\mathrm{R}+\mathrm{D}$ sector will be analyzed. 